\title{
Role of hypoxia-mediated cellular prion protein functional change in stem cells and potential application in angiogenesis (Review)
}

\author{
SEUNG PIL YUN ${ }^{1}$, YONG-SEOK HAN ${ }^{2}$, JUN HEE LEE ${ }^{3}$, YEO MIN YOON ${ }^{2}$, \\ CHUL WON YUN ${ }^{2}$, PETER RHEE ${ }^{1}$ and SANG HUN LEE ${ }^{2}$ \\ ${ }^{1}$ Department of Neurology, Neuroregeneration and Stem Cell Programs, Institute for Cell Engineering, \\ The Johns Hopkins University School of Medicine, Baltimore, MD 21287, USA; ${ }^{2}$ Department of \\ Biochemistry, Medical Science Research Institute, Soonchunhyang University College of Medicine, \\ Cheonan, South Chungcheong 31151, Republic of Korea; ${ }^{3}$ Department of Pharmacology and Toxicology, \\ University of Alabama at Birmingham School of Medicine, Birmingham, AL 35294, USA
}

Received September 8, 2016; Accepted June 19, 2017

DOI: $10.3892 / \mathrm{mmr} .2017 .7387$

\begin{abstract}
Cellular prion protein $\left(\mathrm{PrP}^{\mathrm{C}}\right)$ can replace other pivotal molecules due to its interaction with several partners in performing a variety of important biological functions that may differ between embryonic and mature stem cells. Recent studies have revealed major advances in elucidating the putative role of $\operatorname{PrP}^{\mathrm{C}}$ in the regulation of stem cells and its application in stem cell therapy. What is special about $\operatorname{PrP}^{\mathrm{C}}$ is that its expression may be regulated by hypoxia-inducible factor (HIF)-1 $\alpha$, which is the transcriptional factor of cellular response to hypoxia. Hypoxic conditions have been known to drive cellular responses that can enhance cell survival, differentiation and angiogenesis through adaptive processes. Our group recently reported hypoxia-enhanced vascular repair of endothelial colony-forming cells on ischemic injury. Hypoxia-induced AKT/signal transducer and activator of transcription 3 phosphorylation eventually increases neovasculogenesis. In stem cell biology, hypoxia promotes the expression of growth factors. According to other studies, aspects of tissue regeneration and cell function are influenced by hypoxia, which serves an essential role in stem cell HIF-1 $\alpha$ signaling. All these data suggest the possibility that hypoxia-mediated $\mathrm{PrP}^{\mathrm{C}}$ serves an important role in angiogenesis. Therefore, the present review summarizes the characteristics of $\mathrm{PrP}^{\mathrm{C}}$, which is produced by HIF-1 $\alpha$ in hypoxia, as it relates to angiogenesis.
\end{abstract}

Correspondence to: Professor Sang Hun Lee, Department of Biochemistry, Medical Science Research Institute, Soonchunhyang University College of Medicine, 44 Suncheonhyang 4-gil, Cheonan, South Chungcheong 31151, Republic of Korea

E-mail: jhlee0407@sch.ac.kr

Key words: angiogenesis, hypoxia, cellular prion protein, anti-oxidant, tissue regeneration

\section{Contents}

1. Introduction

2. The effect of hypoxia-preconditioning in cultured stem cells

3. $\operatorname{PrP}^{\mathrm{C}}$ expression is increased under hypoxic conditions

4. HIF-1 $\alpha$ regulates $\operatorname{PrP}^{\mathrm{C}}$

5. Anti-oxidative effect of $\operatorname{PrP}^{\mathrm{C}}$

6. Role of $\operatorname{PrP}^{\mathrm{C}}$ in endothelial cells under angiogenesis

7. The function of $\operatorname{PrP}^{\mathrm{C}}$ in tissue regeneration

8. Conclusion

\section{Introduction}

Prions are neuro-degenerative disease-causing agents, that are responsible for changing cellular prion protein $\left(\mathrm{PrP}^{\mathrm{C}}\right)$ to the infectious $\beta$-structure-rich insoluble conformer $\left(\mathrm{PrP}^{\mathrm{SC}}\right)$ in the neurons of the brain and spinal cord, as in Creutzfeldt-Jakob disease in humans and Bovine Spongiform Encephalopathy in animals (1). $\operatorname{PrP}^{\mathrm{C}}$ is known for its involvement in regenerative processes including adhesion, proliferation, differentiation and angiogenesis. According to Stella et al (2), muscles with low $\mathrm{PrP}^{\mathrm{C}}$ grow slowly compared with wild-type muscles, suggesting that $\mathrm{PrP}^{\mathrm{C}}$ serves a role in tissue recovery and/or regeneration. For these reasons, recent research has focused on obtaining more conclusive information about the functional role of $\mathrm{PrP}^{\mathrm{C}}$ in tissue regeneration. Additionally, regulating $\mathrm{PrP}^{\mathrm{C}}$ expression by hypoxia has become an important topic (3). Hypoxia occurs when blood oxygen concentrations are insufficient and long periods of hypoxia can induce cell death. However, temporary or short periods of exposure to hypoxic conditions actually enhances cell survival by increasing hypoxia-inducible factor-1 (HIF-1), composed of $\alpha$ - and $\beta$-subunits, in addition to other transcription factors (4-6). During hypoxia, an alteration in HIF-1 expression is essential for metabolic adaptation $(7,8)$, as HIF-1 $\alpha$ is associated with angiogenesis and growth factors, glucose uptake, and metabolism (8). Therefore, the present review focuses on the association between $\mathrm{HIF}-1 \alpha$ and $\operatorname{PrP}^{\mathrm{C}}$ in stem cells. It will also examine how HIF-1 $\alpha$-mediated $\operatorname{PrP}^{C}$ expression can serve a role in angiogenesis. 


\section{The effect of hypoxia-preconditioning in cultured stem cells}

According to previous studies, under hypoxic conditions, aged mesenchymal stem cells (MSCs) increase the secretion of angiogenic and anti-apoptotic related growth factors including vascular endothelial growth factor (VEGF), fibroblast growth factor (FGF)-2, human growth factor (HGF) and insulin growth factor-1, resulting in enhanced angiogenic properties (9-12). To demonstrate the effect of growth factor secretion in MSCs under hypoxic conditions, a recent study transplanted hypoxia-conditioned stem cell media into rats with traumatic brain injury and demonstrated excellent rescue effects when compared to animals transplanted with normoxia-conditioned media (13). To observe the effect of restorative neurological function Chang et al (13) transplanted media from hypoxia-treated bone marrow (BM)-MSCs into rats with brain injury rat model and demonstrated that it was more efficient compared with normoxia conditioned medium. Chang et al (13) also demonstrated that the neuroprotective effect of hypoxia-conditioned media involved the generation of VEGF and HGF, which are associated with the inducement of endogenous neurogenesis. In another study, the therapeutic activity of MSCs under hypoxia or normoxia was compared in a massive hepatectomy rat model. In vitro, the levels of VEGF in MSCs under hypoxia were markedly higher than normoxia condition. In vivo, MSCs under hypoxia significantly elevated the expression of cyclin D1, proliferating cell nuclear antigen-positive hepatocytes, the liver weight/body weight ratio and survival when compared with normoxia. Notably, the therapeutic effect of hypoxia was negated by anti-VEGF antibody-induced blockade of VEGF in vivo (14). Increasing the activity of matrix metalloproteinase- 2 also had a therapeutic effect that was associated with the protection of cardiomyocytes via the inhibition of caspase-3, transforming growth factor $\beta 1$ and the upregulation of B-cell lymphoma 2 apoptosis regulator/Bcl-2 associated protein $\mathrm{X}$ apoptosis regulator ratio (15). According to Lee et al (16), the proliferation and migration of mouse embryonic stem (ES) cells increases upon activation of fibronectin-integrin $\beta 1$ production through HIF- $1 \alpha$ and phosphoinositide 3-kinase/Akt pathways under conditions of hypoxia. Additionally, mouse ES cells that have undergone hypoxic preconditioning exhibit HIF-1 $\alpha-$, mitogen-activated protein kinase- and nuclear factor $\mathrm{\kappa B}$-stimulated interleukin- 6 production (17). Hypoxia preconditioning also facilitates the functional bioactivities of endothelial progenitor cells by mediating the regulation of the signal transducer and activator of transcription 3 (STAT3)-B-cell CLL/lymphoma 3 (BCL3) axis. Therefore, expansion and functional bioactivities of endothelial progenitor cells (EPCs) through modulation of the hypoxia-induced STAT3-BCL3 axis can be triggered by a hypoxic preconditioned $e x$ vivo expansion protocol. It has been suggested that hypoxia preconditioning of EPCs may offer a therapeutic strategy for accelerated neovasculogenesis in ischemic diseases (18). In summary, the hypoxic conditioning of cultured stem cells can result in increased production and secretion of trophic factors, augmentation of angiogenic effects and enhanced anti-apoptotic activity from conditioned cells compared with normoxic conditioned culture.

\section{3. $\operatorname{PrP}^{\mathrm{C}}$ expression is increased under hypoxic conditions}

Oxygen is an indispensable element required for biological energy (19). Thus, it is not surprising that a lack of oxygen causes cell damage (20). Oxygen concentrations within the vascular system that supplies mammals with oxygen vary: The heart and arteries have oxygen concentrations that range from $10-14 \%$ (21); however, the majority of tissues contain $<5 \%$ oxygen, while bone marrow and the thymus contain $<1 \%$ oxygen (22-24). At the cellular level, microenvironment changes are important for cell function. For example, EPC proliferation and cell functions have been demonstrated to be enhanced in hypoxic cultures (18). Jeong et al (25) revealed that hypoxia can protect neurons from PrP fragment-induced apoptosis and can increase $\operatorname{PrP}^{\mathrm{C}}$ expression, suggesting that HIF-1 $\alpha$ mediates $\operatorname{PrP}^{\mathrm{C}}$ expression. $\operatorname{PrP}^{\mathrm{C}}$ is generated in the early stages of embryogenesis $(26,27)$ and exists in high levels in neurons of the brain and spinal cord (28). However, glial cells of the central nervous system, and a number of peripheral cell types in adults, possess lower levels of $\operatorname{PrP}^{\mathrm{C}}(29,30)$. The majority of $\operatorname{PrP}^{\mathrm{C}}$ molecules lie on the cell surface and are attached to the lipid bilayer through a C-terminal, glycosyl-phosphatidylinositol anchor (31).

\section{HIF-1 $\alpha$ regulates $\operatorname{PrP}^{\mathrm{C}}$}

Under hypoxic conditions, HIF, a protein with a basic helix loop helix-Per/ARNT/Sim structure (32), regulates the expression of various target genes (33-35). HIF can be categorized into several types according to its subunits, which comprise an $\mathrm{O}_{2}$-regulated $\alpha$-subunit (i.e., HIF- $1 \alpha,-2 \alpha$ or $-3 \alpha$ ) and a constitutively expressed $\beta$-subunit of the Aryl hydrocarbon nuclear translocator (ARNT) family (i.e., ARNT, ARNT2 or ARNT3). Under hypoxic conditions, HIF is inactivated by HIF-a degradation via von Hippel-Lindau E3 ubiquitin ligase (36); however, HIF can still function as a transcription factor by binding HIF- $1 \alpha$ and ARNT, consequently increasing the expression of cell growth, proliferation and pro-angiogenesis factors. This is particularly the case for HIF-regulated pro-angiogenic genes including TEK receptor tyrosine kinase, monocyte chemoattractant protein-1, VEGF, basic FGF, angiopoietin (ANGPT)1, ANGPT2 and platelet-derived growth factor (37). HIF-regulated pro-angiogenic factors initiate the HIF-specific angiogenic program by increasing propagation, adhesion, tube formation, migration, vascular permeability and endothelial cell proliferation $(38,39)$. HIF broadly targets pro-angiogenic genes and comprehensively regulates angiogenesis. Thus, HIF is often termed a 'master-regulator of angiogenesis'. As previously mentioned, $\mathrm{PrP}^{\mathrm{C}}$ also is regulated by HIF, and $\mathrm{PrP}^{\mathrm{C}}$ expression is increased under hypoxic conditions. Park et al (3) demonstrated that the effects of HIF-1 $\alpha$ and $\operatorname{PrP}^{\mathrm{C}}$ on neuronal cell death are prion peptide-induced. In hypoxic conditions, neurons are protected from PrP-induced cell death via the activation of p65 and HIF- $1 \alpha$ and subsequent inactivation of p21 and p53 signals. Deferoxamine-elevated HIF-1 $\alpha$ has similar effects to the hypoxia-mediated inhibition of neuronal cell death under normoxic conditions. Furthermore, knockdown of HIF- $1 \alpha$ leads to the downregulation of $\operatorname{PrP}^{\mathrm{C}}$ expression under hypoxic conditions. 


\section{Anti-oxidative effect of $\operatorname{PrP}^{\mathrm{C}}$}

Numerous enzymes have copper or zinc as essential cofactors, as in the case of cytochrome $c$ oxidase, tyrosinase, various metalloproteinases and $\mathrm{Cu} / \mathrm{Zn}$ superoxide dismutase 1 (SOD1) $(40,41)$. It has been demonstrated that $\operatorname{PrP}^{\mathrm{C}}$ has an antioxidant effect relative to the level of copper, and that the level of this effect does not significantly vary between recombinant and tissue-purified $\operatorname{PrP}^{\mathrm{C}}$, although the molecular mechanism of the antioxidant properties exhibited by $\operatorname{PrP}^{\mathrm{C}}$ remains to be elucidated $(42,43)$. Nonetheless, it has been indicated that the decrease in oxidative stress is mediated by the interaction of copper and $\operatorname{PrP}^{\mathrm{C}}(44)$. Therefore, it is suggested that $\mathrm{PrP}^{\mathrm{C}}$ has a similar effect to the function of antioxidant enzymes including SOD1 (45). However, changes in expression levels of $\operatorname{PrP}^{\mathrm{C}}$ do not induce changes in the activation levels of SOD1 (46). $\mathrm{PrP}^{\mathrm{C}}$ knockout cells are more sensitive to copper toxicity by oxidative stress when compared with wild-type cells (47). Similarly, cerebellar cells obtained from $\operatorname{PrP}^{\mathrm{C}}$ null mice are more vulnerable to oxidative stress than wild type cells $(45,47)$. The deletion of octapeptide repeats within $\operatorname{PrPC}^{\mathrm{C}}$ inhibits the antioxidant properties of $\operatorname{PrP}^{\mathrm{C}}(42)$. Indeed, $\operatorname{PrP}^{\mathrm{C}}$ null mice are more sensitive to acute seizures (48). Therefore, it appears that the status of anti-oxidative defense in $\operatorname{PrP}^{\mathrm{C}}$ null mice serves as an important factor in determining their lower thresholds of damage when reflecting the severity of injury and clinical pathology (49-51). Furthermore, in the skeletal muscles, heart and liver of $\mathrm{PrP}^{\mathrm{C}}$ null mice, its absence greatly increases protein and lipid oxidation, leading to a lower catalase activity (50). Thus, being reduced in free $\mathrm{Cu} / \mathrm{Zn}$, via SOD and glutathione reductase in oxidative stress, $\operatorname{PrP}^{\mathrm{C}}$ may have influence in the resistance against oxidative stress. Sauer et al (52) demonstrated that overexpression of $\mathrm{PrP}^{\mathrm{C}}$ completely inhibits reactive oxygen species generation, even with increased activation treatment with adenosine triphosphate. This is in accordance with the hypothesis that $\operatorname{PrP}^{\mathrm{C}}$ may have a function in protecting against oxidative stress as a free radical scavenger or a molecular sensor (52).

\section{Role of $\operatorname{PrP}^{\mathrm{C}}$ in endothelial cells under angiogenesis}

Endothelial cells express and present $\operatorname{PrP}^{\mathrm{C}}$ on their surface (53). As resting vascular endothelial cells exhibit minimal or no $\mathrm{PrP}^{\mathrm{C}}$ in vivo, normal resting endothelial cells of the umbilical cord and adult blood vessels (aorta, saphenous vein and normal transplant endothelial cells) did not produce detectable quantities of $\operatorname{PrP}^{\mathrm{C}}(54)$. $\mathrm{PrP}^{\mathrm{C}}$ is expressed in endothelial cells of the blood capillaries in the intestinal wall of the digestive tract and in renal capillaries (55). Another study noted a sudden increase in expression of $\operatorname{PrP}^{\mathrm{C}}$ on the surface of endothelial cells, astrocytes and neurons in penumbra regions in a rat model of cerebral ischemia (56). Endothelial cells can express $\operatorname{PrP}^{\mathrm{C}}$ and release it through the cell membrane, as a soluble protein and as a form bound to microparticles, while vascular endothelium may be an origin for $\mathrm{PrP}^{\mathrm{C}}$ released within the blood $(53,57,58)$. $\operatorname{PrP}^{\mathrm{C}}$ has been demonstrated to be a component of caveolae, which are the lipid raft of flask-shaped membrane invaginations in endothelial cells that take part in signal transduction associated with cell survival, differentiation and angiogenesis (59). Another study suggested that caveolae have functions in angiogenesis, as implied by the involvement of caveolae in VEGF signaling in the endothelium (60). This signaling mechanism confirms a key function for caveolae, and possibly $\mathrm{PrP}^{\mathrm{C}}$, in the regulation of angiogenesis (59). Satoh et al (61) identified that disruption of the $\operatorname{PrP}^{\mathrm{C}}$ gene results in abnormal regulation of genes important for cell proliferation, differentiation and survival, including Ras and Rac signaling pathways connected to angiogenesis. During development, neonatal brain endothelial cells temporarily express $\operatorname{PrP}^{\mathrm{C}}$ transcripts, indicating a role in central nervous system angiogenesis and blood-brain barrier maturation $(62,63)$. $\operatorname{PrP}^{\mathrm{C}}$ expression may be regulated by various growth factors through protein-protein interactions with normal protease sensitive $\operatorname{PrP}^{\mathrm{C}}(52,64,65)$.

\section{The function of $\operatorname{PrP}^{\mathrm{C}}$ in tissue regeneration}

Muscle regeneration and its association with $\operatorname{PrP}^{\mathrm{C}}$ has been investigated in a cardiotoxin-induced injury animal model (2). Adult stem cells have the ability to regenerate specific tissues, recapitulating mechanisms observed during morphogenesis (17). Experiments conducted by Stella et al (2) indicated that cardiotoxin-degenerated skeletal muscles release tumor necrosis factor- $\alpha$ (TNF- $\alpha$ ), which is affected by $\operatorname{PrP}^{\mathrm{C}}$, a factor that is involved in both muscle differentiation and downstream signaling pathways. Thus, in vivo morphogenesis of adult injured muscle tissue can be influenced by $\operatorname{PrP}^{\mathrm{C}}$. Their data also support the possibility that the activity of TNF- $\alpha$ converting enzyme (TACE), which hydrolyzes TNF- $\alpha$ from its precursor, is modulated by $\operatorname{PrP}^{\mathrm{C}}$. Prospective in vitro studies may investigate this hypothesis and elucidate whether the two proteins $\left(\operatorname{PrP}^{\mathrm{C}}\right.$ and TACE) interact directly or indirectly. The current review has provided a number of examples of the interaction of $\mathrm{PrP}^{\mathrm{C}}$ with extracellular proteins or neuronal membranes, e.g., its interaction with $\beta$-secretase 1 , which is glycosaminoglycan-mediated, attenuates $\beta$-secretase cleavage of the amyloid precursor protein (66). Furthermore, the binding of $\operatorname{PrP}^{\mathrm{C}}$ to the N-Methyl-D-aspartic acid receptor 2D subunit attenuates glutamate-induced $\mathrm{Ca}^{2+}$ influx (67). Lastly, the results also substantiated that in muscle tissue, the Akt signaling pathway and the regulation of $\mathrm{p} 38$ by $\mathrm{PrP}^{\mathrm{C}}$ have specific physiological significance. This also suggested that $\mathrm{PrP}^{\mathrm{C}}$ serves a significant role in the regeneration process, specifically in the proliferation and differentiation of myogenic precursor cells (2).

\section{Conclusion}

Recent studies have clearly established hypoxia and HIF-1 $\alpha$ as master regulators of stem cell growth factors. In hypoxia-pretreated stem cells, HIF-1 $\alpha$ mainly controls angiogenesis and tissue regeneration factors, including HGF, VEGF and FGF. Hypoxia has also been revealed to increase the expression of the prion protein and growth factors involved in the function of cells and $\mathrm{PrP}^{\mathrm{C}}$ has been shown to be regulated by HIF-1 $\alpha$. Stella et al (2) have suggested that $\operatorname{PrP}^{\mathrm{C}}$ is involved in muscle differentiation and that it influences the morphogenesis of adult injured tissue in vivo. Additionally, regulation of the $\mathrm{p} 38$ and Akt signaling pathways by $\mathrm{PrP}^{\mathrm{C}}$ has clear physiologic importance in tissue in vivo, in addition to the promotion of tissue regeneration. In conclusion, the present 
review summarized the essential roles of $\operatorname{PrP}^{\mathrm{C}}$ and $\mathrm{HIF}-1 \alpha$ in the promotion of tissue regeneration and in the function of stem cells.

\section{Acknowledgements}

The present study was supported by a National Research Foundation (NRF) grant funded by the Ministry of Education (grant no. 2016R1D1A3B01007727) and a grant from the Korean Health Technology R\&D Project, Ministry of Health and Welfare, Republic of Korea (grant no. HI14C2253). The funders had no role in the study design, data collection or analysis, the decision to publish, or the preparation of the manuscript.

\section{References}

1. Prusiner SB: Prions. Proc Natl Acad Sci USA 95: 13363-13383, 1998.

2. Stella R, Massimino ML, Sandri M, Sorgato MC and Bertoli A: Cellular prion protein promotes regeneration of adult muscle tissue. Mol Cell Biol 30: 4864-4876, 2010.

3. Park JY, Jeong JK, Lee JH, Moon JH, Kim SW, Lee YJ and Park SY: Induction of cellular prion protein $(\mathrm{PrPc})$ under hypoxia inhibits apoptosis caused by TRAIL treatment. Oncotarget 6: 5342-5353, 2015

4. Adams JM, Difazio LT, Rolandelli RH, Luján JJ, Haskó G, Csóka B, Selmeczy Z and Németh ZH: HIF-1: A key mediator in hypoxia. Acta Physiol Hung 96: 19-28, 2009.

5. Benzi G, Gorini A, Arnaboldi R, Ghigini B and Villa RF: Age-related changes by hypoxia and TRH analogue on synaptic ATPase activities. Neurobiol Aging 15: 409-417, 1994.

6. Li L, Zhang X, Yang D, Luo G, Chen S and Le W: Hypoxia increases Abeta generation by altering beta- and gamma-cleavage of APP. Neurobiol Aging 30: 1091-1098, 2009.

7. Nakayama K: Cellular signal transduction of the hypoxia response. J Biochem 146: 757-765, 2009.

8. Ryan HE, Lo J and Johnson RS: HIF-1 alpha is required for solid tumor formation and embryonic vascularization. EMBO J 17: 3005-3015, 1998.

9. Efimenko A, Starostina E, Kalinina N and Stolzing A: Angiogenic properties of aged adipose derived mesenchymal stem cells after hypoxic conditioning. J Transl Med 9: 10, 2011.

10. Han YS, Lee JH, Yoon YM, Yun CW, Noh H and Lee SH: Hypoxia-induced expression of cellular prion protein improves the therapeutic potential of mesenchymal stem cells. Cell Death Dis 7: e2395, 2016.

11. Yuan X, Wang X, Chen C, Zhou J and Han M: Bone mesenchymal stem cells ameliorate ischemia/reperfusion-induced damage in renal epithelial cells via microRNA-223. Stem Cell Res Ther 8: 146, 2017.

12. He J, Cai Y, Luo LM and Liu HB: Hypoxic adipose mesenchymal stem cells derived conditioned medium protects myocardial infarct in rat. Eur Rev Med Pharmacol Sci 19: 4397-4406, 2015.

13. Chang CP, Chio CC, Cheong CU, Chao CM, Cheng BC and Lin MT: Hypoxic preconditioning enhances the therapeutic potential of the secretome from cultured human mesenchymal stem cells in experimental traumatic brain injury. Clin Sci (Lond) 124: 165-176, 2013.

14. Yu J, Yin S, Zhang W, Gao F, Liu Y, Chen Z, Zhang M, He J and Zheng S: Hypoxia preconditioned bone marrow mesenchymal stem cells promote liver regeneration in a rat massive hepatectomy model. Stem Cell Res Ther 4: 83, 2013.

15. Li JH, Zhang $\mathrm{N}$ and Wang JA: Improved anti-apoptotic and anti-remodeling potency of bone marrow mesenchymal stem cells by anoxic pre-conditioning in diabetic cardiomyopathy. J Endocrinol Invest 31: 103-110, 2008.

16. Lee SH, Lee YJ and Han HJ: Role of hypoxia-induced fibronectin-integrin $\beta 1$ expression in embryonic stem cell proliferation and migration: Involvement of PI3K/Akt and FAK. J Cell Physiol 226: 484-493, 2011.

17. Lee SH, Lee YJ and Han HJ: Effect of arachidonic acid on hypoxia-induced IL-6 production in mouse ES cells: Involvement of MAPKs, NF-kappaB, and HIF-1alpha. J Cell Physiol 222: $574-585,2010$.
18. Lee SH, Lee JH, Han YS, Ryu JM, Yoon YM and Han HJ: Hypoxia accelerates vascular repair of endothelial colony-forming cells on ischemic injury via STAT3-BCL3 axis. Stem Cell Res Ther 6: 139,2015 .

19. Semenza GL: Life with oxygen. Science 318: 62-64, 2007

20. Saikumar P, Dong Z, Patel Y, Hall K, Hopfer U, Weinberg JM and Venkatachalam MA: Role of hypoxia-induced Bax translocation and cytochrome c release in reoxygenation injury. Oncogene 17: 3401-3415, 1998

21. Carreau A, El Hafny-Rahbi B, Matejuk A, Grillon C and Kieda C: Why is the partial oxygen pressure of human tissues a crucial parameter? Small molecules and hypoxia. J Cell Mol Med 15: 1239-1253, 2011.

22. Parmar K, Mauch P, Vergilio JA, Sackstein R and Down JD: Distribution of hematopoietic stem cells in the bone marrow according to regional hypoxia. Proc Natl Acad Sci USA 104: 5431-5436, 2007.

23. Braun RD, Lanzen JL, Snyder SA and Dewhirst MW: Comparison of tumor and normal tissue oxygen tension measurements using OxyLite or microelectrodes in rodents. Am J Physiol Heart Circ Physiol 280: H2533-H2544, 2001.

24. Stockwell RA: Morphometry of cytoplasmic components of mammalian articular chondrocytes and corneal keratocytes: Species and zonal variations of mitochondria in relation to nutrition. J Anat 175: 251-261, 1991.

25. Jeong JK, Seo JS, Moon MH, Lee YJ, Seol JW and Park SY: Hypoxia-inducible factor-1 $\alpha$ regulates prion protein expression to protect against neuron cell damage. Neurobiol Aging 33: 1006 e1006-e1-10, 2012.

26. Peralta OA, Huckle WR and Eyestone WH: Expression and knockdown of cellular prion protein (PrPC) in differentiating mouse embryonic stem cells. Differentiation 81: 68-77, 2011.

27. Manson J, West JD, Thomson V, McBride P, Kaufman MH and Hope J: The prion protein gene: A role in mouse embryogenesis? Development 115: 117-122, 1992.

28. Harris DA, Lele P and Snider WD: Localization of the mRNA for a chicken prion protein by in situ hybridization. Proc Natl Acad Sci USA 90: 4309-4313, 1993.

29. Brown KL, Ritchie DL, McBride PA and Bruce ME: Detection of PrP in extraneural tissues. Microsc Res Tech 50: 40-45, 2000.

30. Ford MJ, Burton LJ, Morris RJ and Hall SM: Selective expression of prion protein in peripheral tissues of the adult mouse. Neuroscience 113: 177-192, 2002.

31. Moser M, Colello RJ, Pott U and Oesch B: Developmental expression of the prion protein gene in glial cells. Neuron 14: 509-517, 1995.

32. Kewley RJ, Whitelaw ML and Chapman-Smith A: The mammalian basic helix-loop-helix/PAS family of transcriptional regulators. Int J Biochem Cell Biol 36: 189-204, 2004.

33. Semenza GL and Wang GL: A nuclear factor induced by hypoxia via de novo protein synthesis binds to the human erythropoietin gene enhancer at a site required for transcriptional activation. Mol Cell Biol 12: 5447-5454, 1992.

34. Wang GL and Semenza GL: Characterization of hypoxia-inducible factor 1 and regulation of DNA binding activity by hypoxia. J Biol Chem 268: 21513-21518, 1993.

35. Wang GL, Jiang BH, Rue EA and Semenza GL: Hypoxia-inducible factor 1 is a basic-helix-loop-helix-PAS heterodimer regulated by cellular O2 tension. Proc Natl Acad Sci USA 92: 5510-5514, 1995.

36. Kaelin WG Jr and Ratcliffe PJ: Oxygen sensing by metazoans: The central role of the HIF hydroxylase pathway. Mol Cell 30: 393-402, 2008

37. Fong GH: Mechanisms of adaptive angiogenesis to tissue hypoxia. Angiogenesis 11: 121-140, 2008.

38. Matsui J, Wakabayashi T, Asada M, Yoshimatsu K and Okada M: Stem cell factor/c-kit signaling promotes the survival, migration, and capillary tube formation of human umbilical vein endothelial cells. J Biol Chem 279: 18600-18607, 2004.

39. Tang N, Wang L, Esko J, Giordano FJ, Huang Y, Gerber HP, Ferrara $\mathrm{N}$ and Johnson RS: Loss of HIF-1alpha in endothelial cells disrupts a hypoxia-driven VEGF autocrine loop necessary for tumorigenesis. Cancer Cell 6: 485-495, 2004.

40. Tapiero H, Townsend DM and Tew KD: Trace elements in human physiology and pathology. Copper. Biomed Pharmacother 57: 386-398, 2003.

41. Tapiero $\mathrm{H}$ and Tew KD: Trace elements in human physiology and pathology: Zinc and metallothioneins. Biomed Pharmacother 57: 399-411, 2003. 
42. Brown DR, Wong BS, Hafiz F, Clive C, Haswell SJ and Jones IM: Normal prion protein has an activity like that of superoxide dismutase. Biochem J 344 Pt 1: 1-5, 1999.

43. Brown DR, Clive C and Haswell SJ: Antioxidant activity related to copper binding of native prion protein. J Neurochem 76: 69-76, 2001.

44. Vassallo $\mathrm{N}$ and Herms J: Cellular prion protein function in copper homeostasis and redox signalling at the synapse. J Neurochem 86: 538-544, 2003.

45. Brown DR and Besinger A: Prion protein expression and superoxide dismutase activity. Biochem J 334: 423-429, 1998.

46. Waggoner DJ, Drisaldi B, Bartnikas TB, Casareno RL, Prohaska JR, Gitlin JD and Harris DA: Brain copper content and cuproenzyme activity do not vary with prion protein expression level. J Biol Chem 275: 7455-7458, 2000.

47. Brown DR, Schulz-Schaeffer WJ, Schmidt B and Kretzschmar HA: Prion protein-deficient cells show altered response to oxidative stress due to decreased SOD-1 activity. Exp Neurol 146: 104-112, 1997.

48. Walz R, Amaral OB, Rockenbach IC, Roesler R, Izquierdo I, Cavalheiro EA, Martins VR and Brentani RR: Increased sensitivity to seizures in mice lacking cellular prion protein. Epilepsia 40: 1679-1682, 1999.

49. Dal-Pizzol F, Klamt F, Vianna MM, Schröder N, Quevedo J, Benfato MS, Moreira JC and Walz R: Lipid peroxidation in hippocampus early and late after status epilepticus induced by pilocarpine or kainic acid in Wistar rats. Neurosci Lett 291: 179-182, 2000.

50. KlamtF,Dal-Pizzol F, Conte da Frota ML Jr, Walz R, Andrades ME, da Silva EG, Brentani RR, Izquierdo I and Fonseca Moreira JC: Imbalance of antioxidant defense in mice lacking cellular prion protein. Free Radic Biol Med 30: 1137-1144, 2001.

51. Pereira GS, Walz R, Bonan CD, Battastini AM, Izquierdo I, Martins VR, Brentani RR and Sarkis JJ: Changes in cortical and hippocampal ectonucleotidase activities in mice lacking cellular prion protein. Neurosci Lett 301: 72-74, 2001.

52. Sauer H, Wefer K, Vetrugno V, Pocchiari M, Gissel C, Sachinidis A, Hescheler J and Wartenberg M: Regulation of intrinsic prion protein by growth factors and TNF-alpha: The role of intracellular reactive oxygen species. Free Radic Biol Med 35: 586-594, 2003.

53. Starke R, Drummond O, MacGregor I, Biggerstaff J, Gale R, Camilleri R, Mackie I, Machin S and Harrison P: The expression of prion protein by endothelial cells: A source of the plasma form of prion protein? Br J Haematol 119: 863-873, 2002.

54. Sivakumaran M: The expression of prion protein $(\mathrm{PrPc})$ by endothelial cells: An in vitro culture-induced artefactual phenomenon? Br J Haematol 121: 673-674, 2003.

55. Lemaire-Vieille C, Schulze T, Podevin-Dimster V, Follet J, Bailly Y, Blanquet-Grossard F, Decavel JP, Heinen E and Cesbron JY: Epithelial and endothelial expression of the green fluorescent protein reporter gene under the control of bovine prion protein $(\mathrm{PrP})$ gene regulatory sequences in transgenic mice. Proc Natl Acad Sci USA 97: 5422-5427, 2000.
56. Shyu WC, Lin SZ, Chiang MF, Ding DC, Li KW, Chen SF, Yang HI and Li H: Overexpression of PrPC by adenovirus-mediated gene targeting reduces ischemic injury in a stroke rat model. J Neurosci 25: 8967-8977, 2005.

57. Simak J, Holada K, D'Agnillo F, Janota J and Vostal JG: Cellular prion protein is expressed on endothelial cells and is released during apoptosis on membrane microparticles found in human plasma. Transfusion 42: 334-342, 2002.

58. Starke R, Harrison P, Gale R, Mackie I, Drummond O, MacGregor I and Machin S: Endothelial cells express normal cellular prion protein. Br J Haematol 123: 372-373, 2003.

59. Massimino ML, Griffoni C, Spisni E, Toni M and Tomasi V: Involvement of caveolae and caveolae-like domains in signalling, cell survival and angiogenesis. Cell Signal 14: 93-98, 2002.

60. Feng Y, Venema VJ, Venema RC, Tsai N, Behzadian MA and Caldwell RB: VEGF-induced permeability increase is mediated by caveolae. Invest Ophthalmol Vis Sci 40: 157-167, 1999.

61. Satoh J, Kuroda Y and Katamine S: Gene expression profile in prion protein-deficient fibroblasts in culture. Am J Pathol 157: 59-68, 2000.

62. Li A, Sakaguchi S, Shigematsu K, Atarashi R, Roy BC, Nakaoke R, Arima K, Okimura N, Kopacek J and Katamine S: Physiological expression of the gene for PrP-like protein, PrPLP/Dpl, by brain endothelial cells and its ectopic expression in neurons of PrP-deficient mice ataxic due to Purkinje cell degeneration. Am J Pathol 157: 1447-1452, 2000.

63. Adle-Biassette H, Verney C, Peoc'h K, Dauge MC, Razavi F, Choudat L, Gressens P, Budka H and Henin D: Immunohistochemical expression of prion protein (PrPC) in the human forebrain during development. J Neuropathol Exp Neurol 65: 698-706, 2006

64. Kuwahara C, Kubosaki A, Nishimura T, Nasu Y, Nakamura Y, Saeki K, Matsumoto Y and Onodera T: Enhanced expression of cellular prion protein gene by insulin or nerve growth factor in immortalized mouse neuronal precursor cell lines. Biochem Biophys Res Commun 268: 763-766, 2000.

65. West DC, Rees CG, Duchesne L, Patey SJ, Terry CJ, Turnbull JE, Delehedde M, Heegaard CW, Allain F, Vanpouille C, et al: Interactions of multiple heparin binding growth factors with neuropilin-1 and potentiation of the activity of fibroblast growth factor-2. J Biol Chem 280: 13457-13464, 2005.

66. Parkin ET, Watt NT, Hussain I, Eckman EA, Eckman CB, Manson JC, Baybutt HN, Turner AJ and Hooper NM: Cellular prion protein regulates beta-secretase cleavage of the Alzheimer's amyloid precursor protein. Proc Natl Acad Sci USA 104: 11062-11067, 2007.

67. Khosravani H, Zhang Y, Tsutsui S, Hameed S, Altier C, Hamid J, Chen L, Villemaire M, Ali Z, Jirik FR and Zamponi GW: Prion protein attenuates excitotoxicity by inhibiting NMDA receptors. J Gen Physiol 131: i5, 2008. 